\title{
Regulation of Atrial Natriuretic Factor Release in Man: Effect of Water Immersion
}

\author{
A.L. Gerbes ${ }^{1}$, R.M. Arendt ${ }^{1}$, W. Schnizer ${ }^{2}$, S. Silz ${ }^{3}$, D. Jüngst ${ }^{1}$, J. Zähringer ${ }^{1}$, and G. Paumgartner ${ }^{1}$ \\ ${ }^{1}$ Medizinische Kliniken I und II, \\ ${ }^{2}$ Klinik für Physikalische Medizin und \\ ${ }^{3}$ Institut für Klinische Chemie, Klinikum Großhadern, Ludwig-Maximilians-Universität, München
}

Key words: Atrial natriuretic factor - Water immersion $-\mathrm{Hu}$ man subjects - Plasma levels

The atrial natriuretic factors (ANF) have recently emerged as a novel hormonal system $[3,10]$ that may be implicated in extracellular volume homeostasis [9]. Recently, employing our highly sensitive radioimmunoassay [1], we have demonstrated elevated ANF plasma levels in patients with diseases involving pressure/volume overload $[2,6]$. The physiologic regulation of ANF release in healthy subjects, however, needs further elucidation [7]. Water immersion causes an increase in central venous pressure due to a shift of extracellular volume to the intrathoracic venous bed [4]. This increase in central venous and atrial pressure has been shown to increase diuresis and natriuresis $[5,8]$. In the present study, the hypothesis is tested, that water immersion, via the increase in central venous pressure, stimulates an enhanced release of ANF into the circulation that may contribute to the ensuing diuresis.

Subjects and Methods. Twelve healthy subjects, seven men and five women between the ages of 19 and 33, were investigated after informed consent had been obtained. They were on a regular diet without sodium or water restriction. In the morning, after voiding and complete emptying of the bladder, the subjects assumed a seated position next to the immersion tank for the $1 \mathrm{st} h$ of the experiment. Subsequently, they were immersed up to their necks, maintaining the same seated position in thermoneutral water $\left(34.0^{\circ} \mathrm{C} \pm 0.2^{\circ} \mathrm{C}\right)$ for $1 \mathrm{~h}$. Following an additional hour of sitting outside the bath, the experiment was terminated. Throughout the investigation, $250 \mathrm{ml} / \mathrm{h}$ water were given orally to ensure adequate urine flow. All the urine voided was collected before, 60 , and $120 \mathrm{~min}$ after water immersion and analyzed for sodium and potassium (flame photometry), creatinine (Jaffé reaction), and osmolality (freezing point depression). Blood samples for ANF measurement were obtained before and $10,30,60,70,90$, and $120 \mathrm{~min}$ after immersion. ANF was determined in extracted plasma by radioimmunoassay as described previously [4]. Statistical significance was tested using the two-tailed $t$-test; a $P$ value of less than 0.05 was considered significant.

Abbreviation $: \mathrm{ANF}=$ Atrial natriuretic factor
Results.Water immersion caused a prompt and significant increase of mean basal ANF plasma levels. Within $10 \mathrm{~min}$ a significant elevation by $27 \%$ from $6.5 \pm 0.8 \mathrm{fmol} / \mathrm{ml}$ to $8.3 \pm 1.3 \mathrm{fmol} / \mathrm{ml}$ was observed. A progressive increase of plasma ANF up to $12.0 \pm 2.6 \mathrm{fmol} / \mathrm{ml}$ ( $183 \%$ of baseline levels) occurred during the $60 \mathrm{~min}$ immersion period (Fig. 1). Following the end of the immersion, ANF concentration gradually decreased and returned to baseline values within $1 \mathrm{~h}$ postimmersion.

A marked renal response to central volume expansion by water immersion was observed: following $60 \mathrm{~min}$ immersion urinary volume $(1.4 \pm 0.9$ vs $5.5 \pm 2.6 \mathrm{ml} / \mathrm{min})$, urinary sodium content $(0.19 \pm 0.09 \mathrm{vs} 0.32 \pm 0.12 \mathrm{mmol} / \mathrm{min})$, urinary potassium content $(0.09 \pm 0.05$ vs $0.15 \pm 0.06 \mathrm{mmol} / \mathrm{min})$, osmolality clearance $(2.92 \pm 0.78$ vs $5.29 \pm \overline{1} .26 \mathrm{ml} / \mathrm{min})$, and free water clearance $(-0.98 \pm 1.87$ vs $1.54 \pm 3.02 \mathrm{ml} / \mathrm{min})$ were significantly elevated. They returned to preimmersion levels $1 \mathrm{~h}$ following the end of the water bath. There was no significant change in creatinine clearance $(154 \pm 114$ vs $188 \pm 115 \mathrm{ml} / \mathrm{min})$.

Comment. Our observation, that water immersion rapidly increases ANF plasma levels in healthy human subjects, strongly suggests that elevations of central venous and atrial pressure

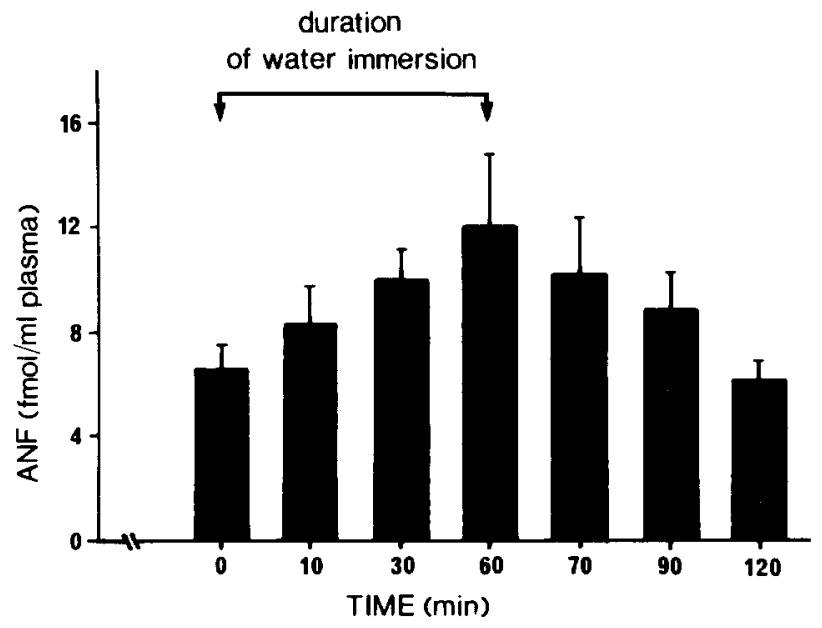

Fig. 1. ANF plasma levels before, during, and after water immersion. Mean values and standard deviation of 12 healthy subjects 
may be physiologic stimuli for ANF release in man. In view of the known renal effects of ANF, this increase of circulating ANF could contribute to the diuresis which follows immersion. The interdependence between ANF and other volume-regulating hormones, however, remains to be investigated.

The present study demonstrates the sensitivity of the ANF system to alterations of volume in healthy humans and suggests an essential role of ANF in the diuresis following water immersion. Water immersion might be a useful model to investigate the response of the ANF system to volume changes in various disease states.

\section{References}

1. Arendt RM, Stangl E, Zähringer J, Liebisch DL, Herz A (1985) Demonstration and characterization of alpha human atrial natriuretic factor in human plasma. FEBS Lett $189: 57-61$

2. Arendt RM, Gerbes AL, Ritter D, Stangl E, Bach P, Zähringer J (1986) Atrial natriuretic factor in plasma of patients with arterial hypertension, heart failure or cirrhosis of the liver. $J$ Hypertension (in press)

3. De Bold AJ, Borenstein HB, Veress AT, Sonnenberg H (1981) A rapid and potent natriuretic response to intravenous injection of atrial myocardial extract in rats. Life Sci 28:89-94

4. Epstein M (1978) Renal effects of head-out water immersion in man: implications for an understanding of volume homeostasis. Phys Rev 58:529-581
5. Gauer OH, Henry JP (1963). Circulatory basis of fluid volume control. Physiol Rev 43:423-481

6. Gerbes AL, Arendt RM, Ritter D, Jüngst D, Zähringer $\mathrm{J}$, Paumgartner $\mathrm{G}$ (1985) Plasma atrial natriuretic factor in patients with cirrhosis. N Engl J Med 313:1609-1610

7. Gerbes AL, Arendt RM, Zähringer J, Paumgartner G (1986) Atrial natriuretic peptide, the sympathetic nervous system, and decompensated cirrhosis. Lancet $1: 331$

8. Henry JP, Gauer O, Reeves IL (1956). Evidence of the atrial location of receptors influencing urine flow. Circ Res $4: 85-90$

9. Laragh JH (1985) Atrial natriuretic hormone, the reninaldosterone axis, and blood pressure-electrolyte homeostasis. N Engl J Med 312:1130-1140

10. Richards AM, Nicholls MG, Ikram H, Webster MWI, Yandle TG, Espiner EAI (1985). Renal, hemodynamic, and hormonal effects of human alpha atrial natriuretic peptide in healthy volunteers. Lancet I : 545-549

Received February 25, 1986

Accepted March 10, 1986

Dr. Alexander L. Gerbes

Medizinische Klinik II, Klinikum Großhadern

Marchioninistr. 15

D-8000 München 70

\section{Buchbesprechungen}

Die Verlage werden gebeten, von der unverlangten Zusendung von Besprechungsexemplaren abzusehen und zunächst eine Anfrage an die Redaktion zu richten, die gegebenenfalls dann ein Exemplar erbitten wird. Für die Rückgabe unverlangt eingesandter Besprechungsexemplare kann keinerlei Gewähr übernommen werden.

Kretz F-J (Hrsg) Intensivmedizin für Krankenpflegeberufe. Thieme, Stuttgart New York 1985. 390 S., 101 Abb., 17 Tab. brosch. DM 33, -..

Dies ist ein ausgezeichnetes Buch, man kann sich höchstens fragen, was seine Besprechung in der Klinischen Wochenschrift soll, vor allem wenn man bedenkt, daß die Besprechung von Lehrbüchern nicht in den Aufgabenbereich der Zeitschrift gehört. Dic Antwort ist einfach. Ein Buch wie "Intensivmedizin für Krankenpflegeberufe" gehört in die Handbücherei jedes jüngeren Universitätslehrers, der Anfänger zu unterrichten hat. - So sehr man paramedizinisches Wissen beim Pflegepersonal und bei jungen Ärzten schätzt, so wenig dürfte es nötig sein, pseudowissenschaftliche Ansichten in einem Buch mit der geschilderten Zielsetzung zu verbreiten. Allgemeinplätze wie auf S. 48 „Beim Zellzerfall werden die in der Zelle befindlichen Enzyme ins Blut freigesetzt“ sollte man nicht drucken. Kein Wort davon ist zutreffend, und die gelieferte Information nützt wenig. - Die Feststellung, daB die Autoren des Buches gelegentlich den Bereich ihrer Kompetenzen verlassen, ändert nichts an der Qualifikation. Man merkt an allen Orten und Enden, daB eine erfahrene Krankenschwester an den Formulierungen beteiligt war. Schwester Agnes Kretz muB man für die Mühe, die sie sich gegeben hat, danken. Dem Verlag möchte man für die nächste Auflage einen besseren Títel für dieses Buch wünschen, welches weit über die Intensivmedizin für Pflegebe- rufe hinausgeht. Ließe sich ein Buch wie das vorliegende nicht einfach umarbeiten in eine Medizin für Krankenpflegeberufe oder Medizinische Grundlagen für Krankenpflegeberufe? Meines Erachtens gehört das Buch auch auf den Schreibtisch der Stationsschwester.

N. Zöllner (München)

Langosch W (Hrsg) Psychische Bewältigung der chronischen Herzerkrankungen. Mit einem Geleitwort yon Roskamm H. Springer, Berlin Heidelberg New York Tokyo 1985. XVII, 380 S., 33 Abb., 87 Tab., brosch. DM 108,-.

Psychosoziale Faktoren spielen bei der koronaren Herzkrankheit eine wesentliche Rolle. Sie sind Teil des multifaktoriellen Verursachungsbündels auch der chronischen Herzerkrankung. Diese Tatsache ist in vielen Untersuchungen von Epidemiologen, Psychosomatikern, Psychophysiologen belegt. Es ist erstaunlich, daß diese Erkenntnisse bisher so wenig in dem medizinisch-ärztlichen Alltag berücksichtigt werden und - der breiteren Diagnose entsprechend - sich im erweiterten Therapieangebot wiederfinden. Das geschieht jedoch an einigen wenigen Zentren wie im Rehabilitationszentrum für Herz- und Kreislaufkranke Bad Krozingen e.V., aus dem das Buch stammt. - Das Thema des Buches wird von einschlägigen Autoren breit diskutiert. Psychosoziale Faktoren werden im ersten Teil in grundlegenden Arbeiten dargestellt, wobei verständlicherweise das Typ-A-Verhalten besondere Berücksichtigung findet. Im zweiten Teil sind die psychischen Probleme während des stationären Aufenthaltes chronisch Herzkranker, auch herzoperierter, dargestellt. Im dritten Teil schließen sich Alltagsprobleme für die tägliche Praxis an. Der letzte Teil des Buches 